\title{
Characterising existing buildings as material banks (E-BAMB) to enable component reuse
}

Colin M. Rose MA, BArch, MRes, ARB

EngD candidate, Centre for Urban Sustainability and Resilience,

Department of Civil, Environmental and Geomatic Engineering, University

College London, London, UK (corresponding author:

colin.rose.13@ucl.ac.uk) (Orcid:0000-0002-5059-6530)
Julia A. Stegemann PhD, DIC

Professor of Environmental Engineering, Centre for Resource Efficiency and the Environment, Department of Civil, Environmental and Geomatic Engineering, University College London, London, UK (Orcid:0000-0002-4491-8222)

As-built records for existing buildings tend to be poor. Components that make up the existing building stock must be better characterised to prevent them becoming waste. The first record of materials in an existing building is often the waste report, which classifies materials for waste management and gathers information after the opportunity for higher-value reuse of components has passed. Policy at various levels aims to increase reuse, but an understanding of 'existing buildings as material banks' (E-BAMB) is a necessary precursor to overcoming other barriers. This paper reviews the current means of understanding E-BAMB and identifies its shortfalls. This analysis leads to the conception of a strategy in which the various approaches are organised as an information system. The future role of technology and mandatory provision of E-BAMB information at the planning stage are explored. The proposed system would enable specifiers, manufacturers and academics to assess the wealth of materials that can be reused, repurposed or upcycled in new projects or businesses. This does not guarantee that actual reuse will occur, as financial, technical and legal barriers may remain. However, it creates the context for assessing secondary components against their virgin equivalents and the enabling conditions for new circular business models.

\section{Introduction}

To meet ambitious global greenhouse gas emissions targets, the UK and many other countries must improve emissions associated with buildings (Giesekam et al., 2015). In one scenario investigated by Giesekam et al. (2016), designers must find ways to reduce embodied emissions across all new buildings by $67 \%$ by 2027 to achieve interim targets. An alternative would be to avoid new construction and instead retain and upgrade existing buildings, but this option is often not adopted for reasons that are outside the control of the construction industry (Crawford et al., 2014; Power, 2010; Thomsen and van der Flier, 2011). Once the decision to demolish has been taken, current recycling processes tend to destroy the embodied value of construction materials - for example, by crushing concrete for recovery of aggregate or recovering energy from timber (Rose and Stegemann, 2018). Reuse, the 'inner circle' of the circular economy, is gaining increasing attention as a means of reducing embodied emissions (e.g. Dunant et al., 2017; Gorgolewski, 2008; Ness et al., 2015) and helping to address other global problems such as resource depletion, environmental damage associated with resource extraction and waste disposal and ethical issues on supply of construction materials (Mustow, 2006).

Recent work framing a view of 'buildings as material banks' (BAMB; Debacker and Manshoven, 2016), within which components are retained at high value for future reuse, tends to focus on new buildings (Durmišević, 2015). The intention is to create a future end-of-life building stock composed of recoverable components that will remain useful in the face of unpredictable changes in standards, technology, economics and societal needs. Given that new-build rates are low (e.g. between 0.5 and $1.5 \%$ annually in the UK, Germany, Denmark and the Netherlands (Bell, 2004; Hinnells et al., 2007; Power, 2010; van der Flier and Thomsen, 2006)), the segment of total stock improved by design changes would be modest (Poelman, 2009), even if all new buildings were built according to design for deconstruction and circular economy principles. It is therefore clear that improvement of current construction material management requires consideration of the fate of components and buildings not designed with deconstruction in mind, in particular the existing building stock from the twentieth century.

At present, a limited selection of high-value components is reclaimed and traded by the salvage industry (CRWP and Salvo, 2007). Environmentally beneficial improvements upon dominant recycling processes are not necessarily limited to direct reuse; they may also include repurposing, in which a component is reimagined for a new purpose (Sieffert et al., 2014), and upcycling, in which a third party carries out a non-destructive process that results in a new product of greater value (Kay, 1994). Some may argue that little improvement upon recycling is (currently) feasible for the majority of materials; but this is an assumption. It cannot be tested because information about components, and the components themselves, are not available to the potential demand side of the market. To be able to test this assumption and keep testing it as the economic context evolves, there is a need to reframe 'existing buildings as material banks' (E-BAMB, to coin a term), rather than seeing them as 'waste in waiting' (Giesekam et al., 2015). To support this change, this paper develops a framework for the collection and application of E-BAMB information. The needs of the demand side of the market are taken into account so that the potential to reuse, 
repurpose and upcycle components can be exhaustively checked before they are consigned as waste.

\section{Research objectives and approach}

Reuse is supported by policy at many levels. The EU Waste Framework Directive (EC, 2008) requires member states to embed into law the principle of the waste hierarchy. The Clean Growth Strategy (HMG, 2017), the Waste Management Plan for England (Defra, 2013), the London Environment Strategy (GLA, 2018) and planning policy documents, including The London Plan (GLA, 2016) and local plans, all stress the importance of reuse as a means of waste prevention. Planning guidance in London recommends the application of the waste hierarchy and the use of reclaimed components in preference to materials with recycled content or new products, making existing components that cannot be reused on-site available for reuse elsewhere and sourcing materials locally (GLA, 2014). London's circular economy route map advocates the introduction of targets for reuse in construction and the development of markets for reused products (LWARB, 2017). The sustainability checkpoint in Stage 0 of the Royal Institute of British Architects' (RIBA) Plan of Work 2013 calls for a strategic review 'including reuse of existing facilities, building components or materials' (RIBA, 2013).

However, the waste hierarchy's preferential order can be circumvented (Van Ewijk and Stegemann, 2016) and counterarguments are allowed to justify ignoring planning guidance. If the benefits of reuse, repurposing and upcycling are to be achieved, the policy framework must move from recommendations that favour reuse into enforceable requirements and supporting measures that help to bring it about in the mainstream. Markets for secondary materials are identified by the EU's Circular Economy Package (European Commission, 2015) as an area for development. Specific levers need to be identified and used to create a functioning market in reused building components.

There is consensus in the academic literature that the scarcity of information about the existing building stock acts as a barrier to effective management of end-of-life components (Ali, 2016, 2012; Debacker and Manshoven, 2016; Densley Tingley et al., 2017; Horvath, 2004; Hurley, 2003; Poelman, 2009). Iacovidou and Purnell (2016) explain the need for component quantity, availability, size and properties to be audited and communicated to create liquidity in the market. However, the changes needed to achieve a wholesale shift towards characterisation of E-BAMB are poorly understood. This paper therefore aims to analyse critically the current means of generating E-BAMB knowledge and frame a direction for further work, as a precursor to overcoming other constraints to reclamation and reuse. The goals of this paper are to

- review existing practices and research that can contribute to an understanding of E-BAMB

- examine the limitations of these practices for supporting reuse, repurposing and upcycling
- show how new approaches to generating E-BAMB knowledge can address present shortfalls

- discuss these proposals in the light of other relevant advances to illustrate a scenario for future knowledge of E-BAMB.

\section{Review of E-BAMB research and practice}

\subsection{Categorisation of approaches}

Table 1 identifies existing and emerging practical and research approaches to gathering E-BAMB information, for discussion in the next sections.

\section{2 "As-built" information about existing buildings}

When available, drawings and specifications documenting construction and maintenance of buildings provide a useful reference for further adaptation of buildings or for assessing the potential use of components to be removed from a building. An example is the archive maintained by the UK government of its own estate (The National Archives, 2012). However, where records have been retained through a building's lifespan, they are typically used internally within the project team to aid design, rather than in an aggregated way that could be drawn upon by demand from outside the project team. More often, documents from the time of construction are unavailable, incomplete or unreliable (Brewer and Mooney, 2008; Gorgolewski and Ergun, 2013; Guggemos and Horvath, 2003; Macozoma, 2001; Volk et al., 2014). In the UK, pre-construction drawings submitted for building control approval are deposited with local authorities. Anecdotally, attempts to access and use such records are rarely successful: pre-digital records may not be available; physical drawings may have deteriorated; they may not provide a full, detailed description of components; and construction details may have changed post-submission without updating local authority records. The general scarcity of as-built information means that systems for its use are not in place.

\subsection{Building information modelling for existing buildings: automated scan-to-BIM research}

New buildings will increasingly be accompanied by digital records produced through building information modelling (BIM). Coupled with material passports (Luscuere, 2017; Ness et al., 2015) and the miniaturisation of 'Internet of Things' devices (Heiskanen, 2017), this offers the prospect of a future end-of-life building stock for which comprehensive E-BAMB information will, in some cases, be readily available. It is becoming increasingly efficient to generate BIM for the existing building stock, based on laser scanning and (semi-)automated object recognition processes (Arayici, 2008). This can be used as an alternative to manual survey work to produce as-built drawings of historic structures (Barazzetti et al., 2015; Murphy et al., 2009), and potentially to improve demolition or deconstruction planning (Volk et al., 2014). The process of turning a geometric scan into a 'semantically rich' BIM model with component attributes is in its infancy. However, in due course, texture-based recognition and surface-penetrating scanning techniques may make it possible to identify materials both on and below the surface (Volk et al., 
Table 1. Approaches towards gathering E-BAMB information

\begin{tabular}{|c|c|c|c|c|c|c|}
\hline & & \multicolumn{5}{|c|}{ The demand side can seek information about existing building components by ... } \\
\hline & & \multirow{2}{*}{$\begin{array}{l}\text {... leading } \\
\text { the search } \\
\text { themselves }\end{array}$} & \multicolumn{3}{|c|}{... leveraging practice-based knowledge and networks with a: } & \multirow{2}{*}{$\begin{array}{l}\text {... drawing on } \\
\text { evidence-based } \\
\text { knowledge }\end{array}$} \\
\hline & & & waste producer & $\begin{array}{c}\text { third-party } \\
\text { material handler }\end{array}$ & $\begin{array}{l}\text { third-party } \\
\text { information } \\
\text { handler }\end{array}$ & \\
\hline \multirow{5}{*}{ 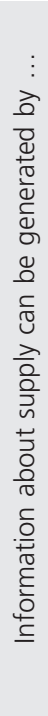 } & $\begin{array}{l}\text {... analysing original } \\
\text { design }\end{array}$ & $\begin{array}{l}\text { As-built } \\
\text { information } \\
\text { (Section 3.2) }\end{array}$ & $\begin{array}{l}\text { As-built information } \\
\text { (Section 3.2) }\end{array}$ & - & $\begin{array}{l}\text { Future: BIM for new } \\
\text { buildings }\end{array}$ & - \\
\hline & $\begin{array}{l}\ldots \text { keeping records of } \\
\text { built assets }\end{array}$ & - & - & - & $\begin{array}{l}\text { Public records; } \\
\text { owners' stock } \\
\text { condition surveys }\end{array}$ & $\begin{array}{l}\text { In-use stock research } \\
\text { (Section 3.4) }\end{array}$ \\
\hline & $\begin{array}{l}\text {... estimating } \\
\text { components while in } \\
\text { use in buildings }\end{array}$ & $\begin{array}{l}\text { Demand-led } \\
\text { 'harvest } \\
\text { mapping' } \\
\text { (Section 3.6) }\end{array}$ & $\begin{array}{l}\text { Supply-led demolition } \\
\text { planning, pre- } \\
\text { redevelopment audits } \\
\text { (Section 3.5) }\end{array}$ & $\begin{array}{l}\text { Salvage industry } \\
\text { expertise }\end{array}$ & $\begin{array}{l}\text { Reused material } \\
\text { marketplaces } \\
\text { (Section 3.7) }\end{array}$ & $\begin{array}{l}\text { In-use stock research } \\
\text { (Section 3.4); waste } \\
\text { prediction research }\end{array}$ \\
\hline & $\begin{array}{l}\text {... applying novel } \\
\text { techniques to } \\
\text { measure components } \\
\text { while in use }\end{array}$ & - & - & - & - & $\begin{array}{l}\text { BIM for existing } \\
\text { buildings: automated } \\
\text { scan-to-BIM research } \\
\text { (Section 3.3) }\end{array}$ \\
\hline & $\begin{array}{l}\text {... identifying once } \\
\text { removed from } \\
\text { building }\end{array}$ & Scavenging & - & $\begin{array}{l}\text { Salvage yards; } \\
\text { waste flow } \\
\text { monitoring } \\
\text { (Section 3.8) }\end{array}$ & $\begin{array}{l}\text { Collated waste } \\
\text { transfer statistics }\end{array}$ & $\begin{array}{l}\text { Waste quantification } \\
\text { research }\end{array}$ \\
\hline
\end{tabular}

BIM, building information modelling

2014), to produce an inventory of existing components (Volk et al., 2015) that could be embedded within an E-BAMB information system. By sharing inventory information when buildings reach their end of life, designers elsewhere would be able to check the forthcoming availability of components and assess their suitability for use in new projects (Swift et al., 2015).

\section{4 'In-use stocks' research}

'In-use stocks' research (Kohler and Hassler, 2002) attempts to describe stocks and flows of materials at city-, region- or countrywide scale (e.g. through material flow analysis (Tanikawa et al., 2002)). These studies rely on various assumptions, such as the homogeneity of material composition across categories of building types and age classes (Augiseau and Barles, 2016), to arrive at overall tonnages of material per capita (e.g. Kral et al., 2014; Tanikawa and Hashimoto, 2009; Wiedenhofer et al., 2015), or material intensity per building area or volume (e.g. Bergsdal et al., 2007; Kleemann et al., 2016). Data at this level allow projections of future material demand and potential secondary material supply, and inform long-term strategic planning of waste management and material recovery (Müller, 2006; Schebek et al., 2017; Vásquez et al., 2016). The findings are not suited to practical application at the project level. In economy-wide studies, most of the materials assessed will remain in use for decades.

Quantification of materials in use (as well as quantification and prediction of waste flows) tends to categorise into material groups for recycling, rather than into component groups for reuse. These studies generally do not grapple with the development of the demand side of a reused component marketplace. However, there are examples of in-use stocks research that have reuse as the specific goal and which narrow the focus to a single component type. Ergun and Gorgolewski (2015) investigated Toronto's detached housing stocks with a particular focus on bricks. Huuhka et al. (2015) developed a detailed inventory of prefabricated concrete panels in Finnish 1970s mass housing. They included qualitative data such as the form and condition of panels, information that is essential to a designer wishing to reuse or an enterprise wishing to assess the feasibility of upcycling such a waste stream. It would be valuable to develop this field further to reach the granularity needed to inform industry at project level.

\subsection{Supply-led demolition/deconstruction planning and pre-redevelopment audits}

The UK Site Waste Management Plans Regulations 2008 (HMG, 2008; repealed 2013) were intended to encourage contractors to predict forthcoming waste streams, partly to allow a proactive approach to reusable components (Resource Efficient Scotland, 2017). It is common for data to be collected only retrospectively by waste management companies, once skips have reached a waste transfer station. By this stage, both the materials and the information about them have become aggregated in a way that reduces their usefulness (Rose and Stegemann, 2018).

Research has emphasised the importance of pre-planning of demolition (Pun and Liu, 2006; Pun et al., 2003). Producing 
appropriately categorised and detailed information about components in advance of demolition creates the possibility of a connection between demolition contractors who would like to sell components for reuse and architects who would like to specify reused components (Gorgolewski, 2000). The demolition protocol (ICE, 2008) and the resource protocol (NFDC and IDE, 2016) seek to bring about early identification of types and quantities of materials arising from demolition. Pre-redevelopment audits (or pre-demolition audits in the former document) combine a deskbased survey of existing information with a site survey to produce an inventory. In the development of the London 2012 Olympic Park, application of the demolition protocol helped to drive the reclamation of nine steel-framed buildings for reuse off-site and on-site recycling of $400000 \mathrm{t}$ of crushed concrete and masonry (Carris, 2011). A reclamation audit was undertaken, and the findings were shared with designers of new parts of the Olympic Park through a database, site visits and workshops (Bioregional, 2011). Although reuse did not play a significant role in meeting the overall target of at least $90 \%$ reuse and recycling for the Olympic Park as a whole, various items were reclaimed and reused (Carris, 2011).

Whereas the Olympic Park development's needs provided a moderate level of demand, a smaller project may present limited opportunities for on-site reuse. Making information from audits available to industry at large - a citywide community of designers and contractors - would enable proliferation of reuse opportunities. However, the value of pre-redevelopment audits is presently limited by the lack of a mechanism for their exposure beyond the boundaries of the project team. Furthermore, as preredevelopment audits are a voluntary tool and attempts such as those made in the Olympic Park development are rare, they are not familiar to specifiers and purchasers as a potential form of supply. Such project-based information gathering needs to be conceived as part of a wider framework that renders them more effective as a form of supply, and hence motivates clients or contractors to produce thorough audits.

\subsection{Demand-led harvest mapping and the 'superuse scout'}

The Dutch architecture practice Superuse Studios have developed an innovative approach to procurement of materials for their projects. In their means-oriented approach to design, the available materials provide the starting point and impetus for meeting the project brief (Pereira et al., 2016). A process known as harvest mapping is used to discover what is available (Jongert et al., 2011; van Hinte et al., 2007). In the early stages of a project, the area around the site is scouted for available waste streams, initially considering a $25 \mathrm{~km}$ radius. Potential sources are visually represented on a map, providing a material catalogue to assist the design team and a means of communicating material choices to the client (Jongert et al., 2011).

The lack of established systems of E-BAMB information means that harvest mapping is a time-consuming process. Superuse Studios extend their remit beyond normal architectural design; they employ staff and consultants to search for and document available materials and host a website with information about one-off and continuous waste streams that could be used by other architects (Superuse Studios, 2017a). They anticipate future codification of this knowledge in a new profession, the 'superuse scout' (van Hinte et al., 2007: p. 14). Superuse Studios' approach offers a compelling alternative vision of practice, and their portfolio (Superuse Studios, 2017b) shows how the application of creativity to information about unwanted materials can lead to new repurposing ideas. However, the change of process involved in means-oriented design (Gorgolewski, 2008), and the additional burdens that the architect would currently take on to implement it, constrain uptake in mainstream construction.

\subsection{Reused material marketplaces: supply-demand interface}

Without ready supply information to draw on, demand-led harvest mapping is time consuming and requires a radical change in approach to design. Without a mechanism for reaching demand beyond isolated project teams, supply-led pre-redevelopment audits are likely to produce little opportunity for reuse. Reused material marketplaces (RMMs) appear to offer a plausible interface between 'supply projects' and 'demand projects': a digital forum for exchanging unwanted items.

Since the 1970s, there have been concerted efforts to form networks comprising generators and users of waste (Chen et al., 2006; Gorgolewski et al., 2006). As information platforms, those focusing on the construction industry function like eBay: sellers post information about available items, and buyers can browse, typically by categories ('plastics', 'bathroom' etc.) and location. Most have exhibited little success (Chen et al., 2006; Rose and Stegemann, 2018; Table S2 in the online supplementary material). To fulfil their potential, RMMs need to serve both the supply and demand side of the market.

From the supply perspective, posting unwanted items on RMMs is not an established practice for contractors (Rose and Stegemann, 2018). There is little incentive to adopt it as a new practice unless there are good prospects of making sales. From the demand perspective, designers require information well in advance of the potential purchase, certainty about the quantity and the quality of the items offered and a wide choice. At present, items are usually offered at the time that they arise as waste rather than in advance. This precludes the opportunity for them to be incorporated into design development. Contractors lack trust in RMMs (Rose and Stegemann, 2018); items may be without warranties guaranteeing quality and fitness for purpose (McGinley, 2015). In terms of choice, the active RMMs identified in Table S2 in the online supplementary material have an average of 143 items currently available, while the product table of Uniclass 2015 (NBS, 2015) lists more than 6700 construction product types. The market segment of demand projects that can take advantage of components made available on RMMs is therefore severely limited by the need to be less selective and to make immediate use of materials. 
Attempts to improve the efficacy of RMMs by using geographic information systems (Ali, 2012; Susanty et al., 2016), big data (Bin et al., 2015) and BIM (Ali, 2012) aim to optimise the gap between supply and demand. However, they do little to address the fundamental barriers to use of RMMs on the demand side or the consequent lack of motivation to offer materials on the supply side. To be more effective, the RMM platform needs to fit into a strategy for gathering structured and timely information from a wide range of supply projects, demand projects or both. Partnering approaches, such as Royal BAM Group working with IBM on a new 'circular building platform', may garner significant volumes of supply and demand data through the direct involvement of a major construction company and thus increase the likelihood of creating effective exchanges. New RMMs would also benefit from making a thorough diagnosis of the reasons for previous failures.

\subsection{Waste flow monitoring}

When none of the aforementioned approaches are taken, the first picture of a building's material content comes as a set of waste streams. In typical current practice, monitoring is undertaken at waste transfer stations, at which point materials have been treated as waste (e.g. by being crushed mechanically for ease of handling) and are described as waste under European Waste Catalogue codes (EC, 2000). Although not without value to contractors and clients, industry monitoring of waste flows and research quantifying waste (e.g. Bossink and Brouwers, 1996; Coelho and de Brito, 2011; Hobbs et al., 2011; Wu et al., 2014) are too late to aid in reclaiming components for reuse (Rose and Stegemann, 2018). Furthermore, description in terms of undifferentiated tonnage or volume of broad waste categories, rather than capturing qualitative and granular information about components, fails to provide a retrospective understanding of E-BAMB.

\section{A coordinated approach to E-BAMB knowledge generation}

\subsection{Introduction}

To address the weaknesses identified earlier, a coordinated information system that draws on and develops out of existing practices is proposed. At the centre is an E-BAMB database, or virtual warehouse, like an RMM embellished with information from refocused pre-redevelopment audits, in-use stocks research and scan-to-BIM research (Figure 1).

\subsection{Audit: focus of data collection and nature of data}

For the reuse opportunities identified in pre-redevelopment audits to be more clearly apparent, the description of components should be based on an established classification system (e.g. the elements or product table of Uniclass 2015 or the Common Arrangement of Work Sections (CPIC, 1998)) rather than on waste categories. The audit should capture qualitative information in the form of a photograph in the first instance, alongside location, expected timing, approximate quantities and potential savings of embodied greenhouse gas emissions ('embodied carbon'; hereafter, 'carbon' refers to greenhouse gas emissions) (Bioregional, 2011; Iacovidou and Purnell, 2016). If as-built records exist, this will provide the starting point for the audit, although changes to the building over its lifetime may require this information to be updated. In the future, there may be more efficient ways to create inventories of existing building components, such as through the use of detailed models developed by in-use stocks researchers or automated scanto-BIM technology.

\subsection{Submission: responsibility and timing}

Since pre-redevelopment audits are currently voluntary and because there is no mechanism for sharing results beyond the project team, E-BAMB information is rarely produced and scrutinised as a potential form of supply. Once there is a track record of successful examples of materials being identified, reclaimed, profitably sold and reused, the motivation to carry out audits can confidently be expected to increase. However, a legislative nudge appears necessary to create the conditions for such examples to emerge and build the evidence and confidence to support widespread adoption. For example, the production of E-BAMB information could be achieved by making a preredevelopment audit mandatory for planning consent for projects (above a certain size threshold) that involve demolition or soft strip. If initially the threshold is set high, this would focus attention on developments with the largest potential for waste prevention gains. The threshold could be lowered incrementally, in tandem with a growing capacity in the industry for carrying out audits, reclamation, storage and demand for secondary components. As norms shift and these processes become common practice, transaction costs would drop.

Materials advertised on RMMs are often about to be discarded, limiting demand to those projects that can make immediate use of materials (Figure 2). Projects that cannot make immediate use of materials would rely on a 'supply and demand storage buffer' (RSA and The Great Recovery, 2015) until they have reached construction stage (Figure 3). Introducing the requirement for a pre-redevelopment audit at the planning stage creates a period of time for identified components to be incorporated into demand projects' design development, specified and procured (Figure 4). Time frames of projects often differ from estimates, making the coordination of a supply project and a demand project difficult. This problem would be diminished by an increasing number of engaged supply and demand projects; at full city scale, for instance, it would become easier to find a timely substitute for common components. Rarely will the need for intermediate storage be eliminated altogether, but it may be reduced to an extent that makes warehouse costs or site storage viable.

\subsection{Broadcast: collation and sharing of information}

E-BAMB information submitted to the local authority at planning stage in a standardised format can be collated in a virtual warehouse, broadcast online and promoted to the demand side of the market. Many potential new uses could be expected to emerge from the collective creativity of designers, contractors, manufacturers, entrepreneurs and academics. For example, a study of components 


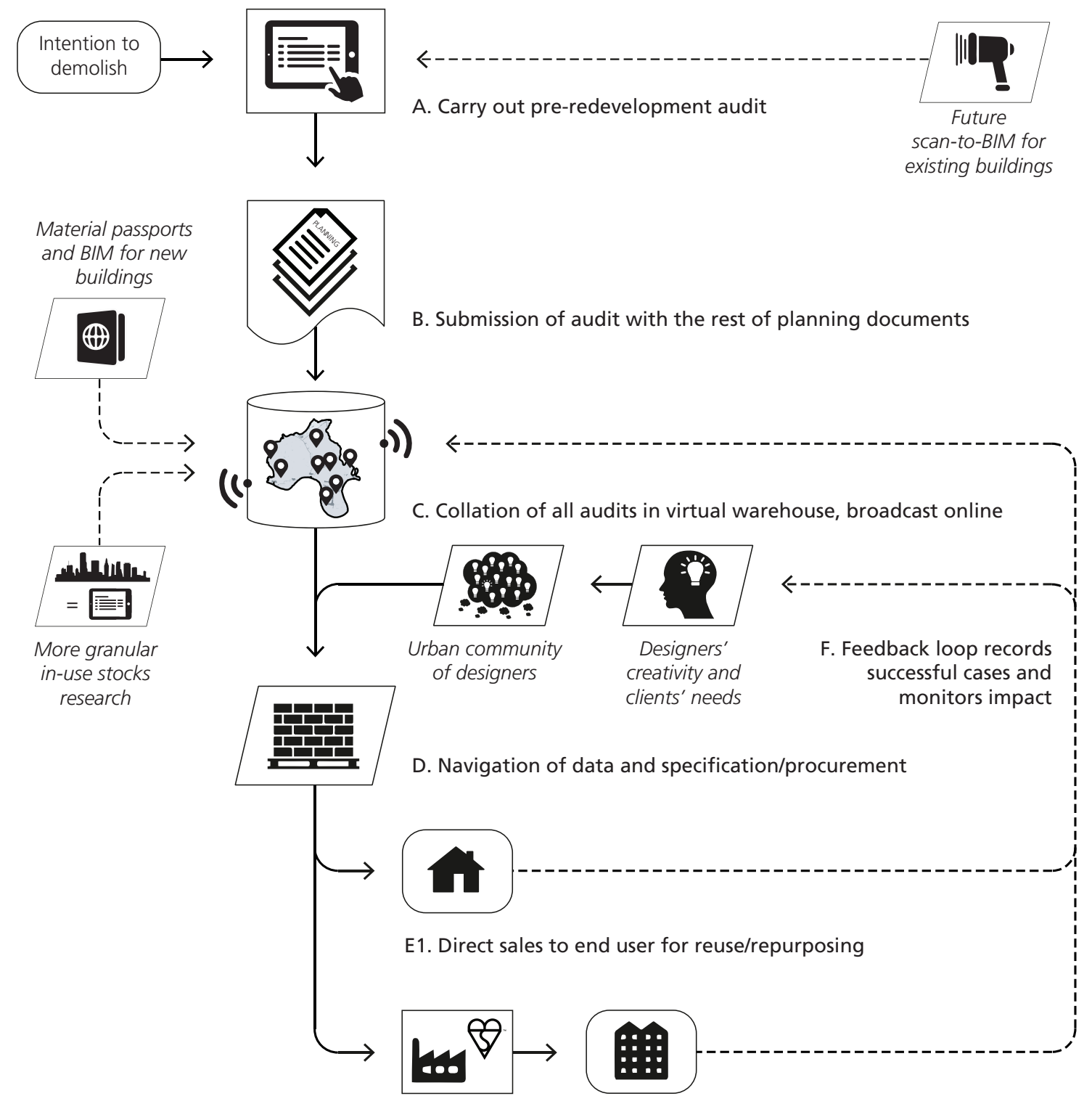

E2. Supply to third-party upcyclers and onwards to end user

Figure 1. E-BAMB information system flow diagram. Collectively these steps form part of a 'triage process' that separates components for reuse, repurposing and upcycling from those for which downcycling or energy recovery is the best option (Rose and Stegemann, 2018)

from decommissioned oil and gas rigs exposed the results of a 'pre-landing audit' to various industry participants in an ideas workshop. In $2 \mathrm{~h}, 13$ participants had come up with 186 unique ideas for 24 identified components (RSA and The Great Recovery, 2015). An ideas workshop is not bound by the need to implement proposals, but if E-BAMB information were to reach a large urban community, reuse ideas would be driven by real needs as well as collective creativity. For instance, prefabricated concrete building components that appear to have no use in their original form may be repurposed as a hard landscaping surface instead of new paving; as thermal mass inside a glazed foyer; or, after being cut and polished, as a backdrop to café seating. Many ideas may prove unfeasible, but casting a wide net increases the chances of the emergence of successful reuse, repurposing and upcycling opportunities.

\subsection{Navigation: accessing and using information}

Ongoing developments in electronic search capability will enable efficient scouring of a large E-BAMB database. In addition to the ability to search by location and material type, the use of an established classification system in the audit (as discussed in Section 4.2) would allow categories of product to be matched 


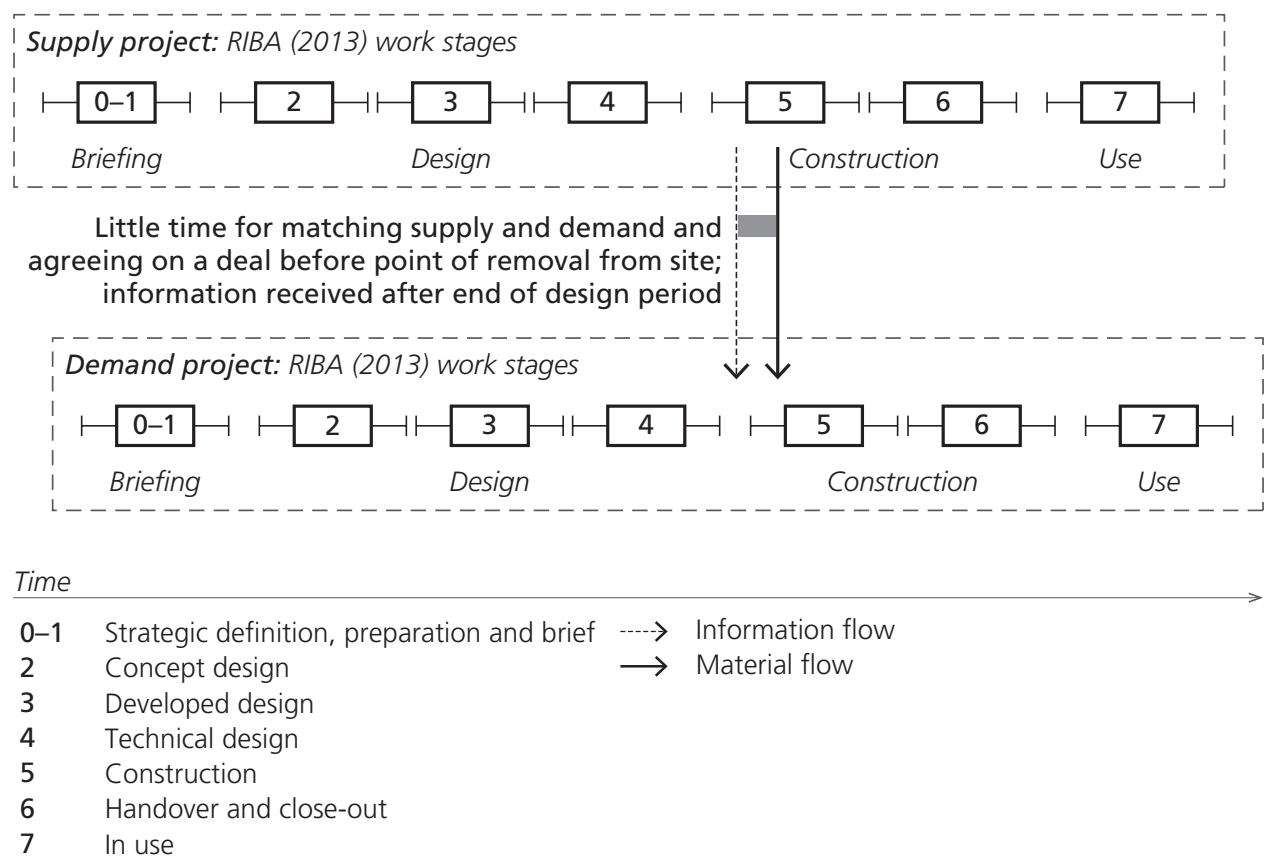

Figure 2. Typical use of an RMM to facilitate direct exchange between supply and demand projects. Components are not identified in advance, so a demand project receives components and immediately uses them in construction. There is some potential for direct substitution of specified products, but generally, reused components will need to be designed in to the scheme during stages $2-4$. Thus, types of demand projects that can reuse or repurpose components at a late stage are severely limited

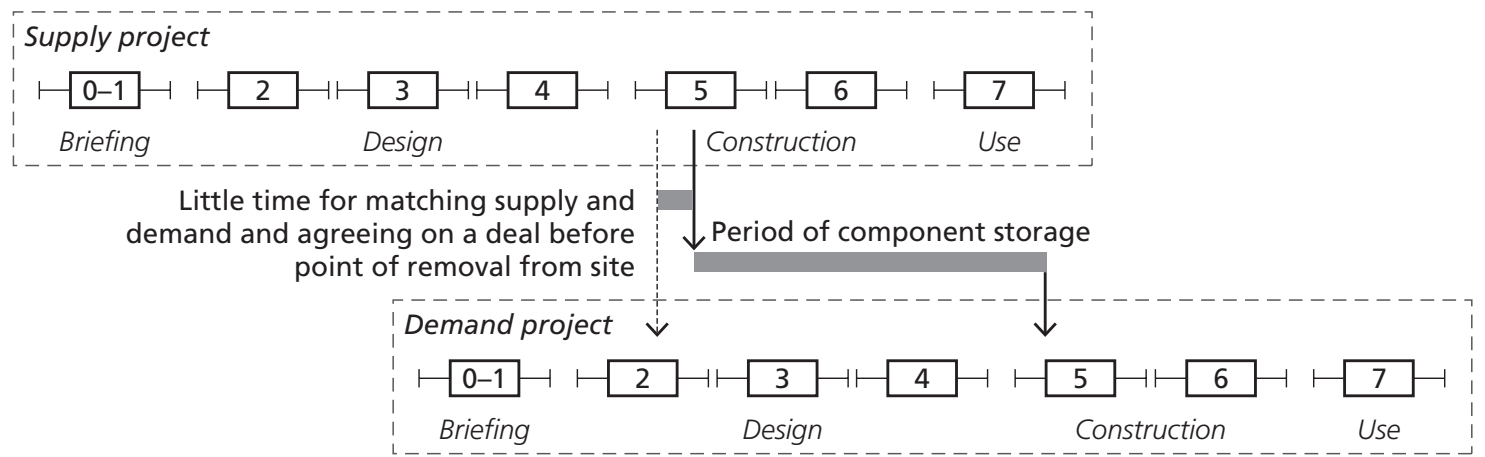

Figure 3. Use of RMM with storage available on one or another site or in a separate storage facility. Reuse or repurposing is designed in to the demand project during stages 2-4 and components used later when they reach stage 5 . There is risk of components being put into storage but ultimately not used. Storage may be prohibitively expensive (for legend, refer to Figure 2)

automatically against demand requirements. Less conventional search capability will be required to identify value-adding repurposing of a component from one product category to serve a function in another. Repurposing is a creative act, but this creativity could be codified within the database by linking instances of components' transfer from original uses to new uses. Revisiting the prefabricated concrete example, if one exchange saw panels successfully repurposed as hard landscaping, the database could flag forthcoming sources of prefabricated concrete panels for the next demand project seeking hard landscaping. Thus, a niche repurposing project has a trajectory to a repeated application and potentially to high-volume upcycling, facilitated at scale by a third party.

Having identified possible candidates for reuse, demand projects' designers would need to find out further information in the same way that they would for a new component. Whereas the investment of time in researching a conventional product may be expected to pay back through use in multiple projects, reclaimed components are likely to need new investigations each time. Detailed qualitative and quantitative audit information in the first instance will minimise the need for site visits to gather more 


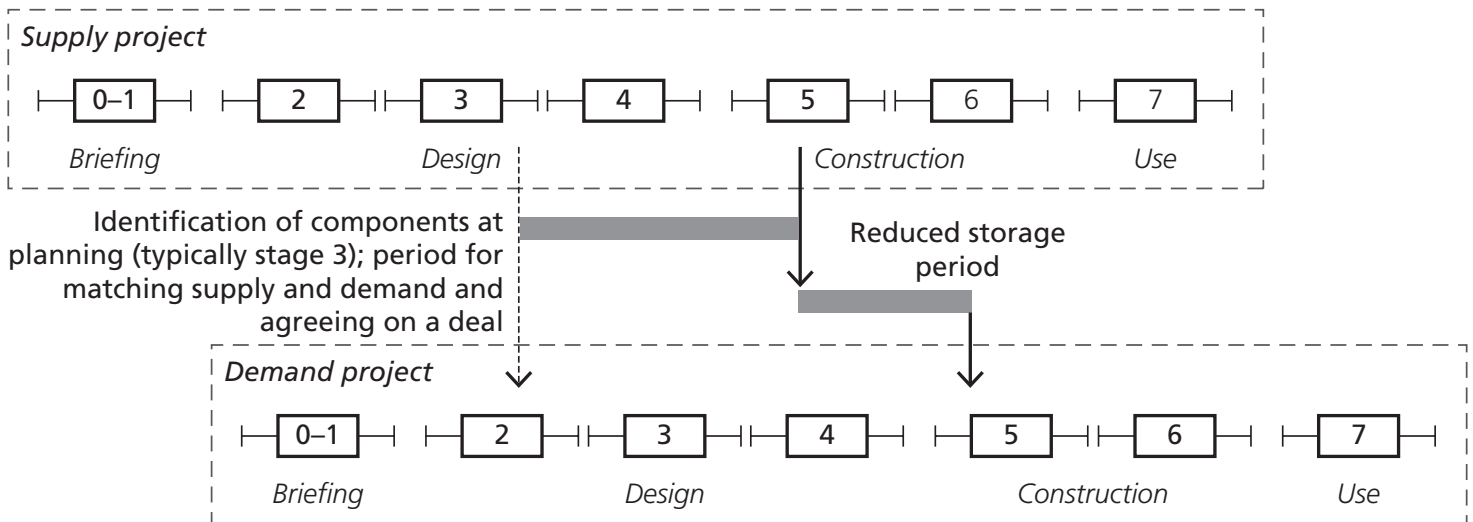

Figure 4. Early production of E-BAMB information. The supply project is chosen on the basis of similar expected start on-site, to avoid or minimise the period of storage. Reuse or repurposing is designed in to the demand project during stages 2-4; further component information is gathered as necessary; condition of components post-reclamation is agreed and price negotiated. The storage period is reduced but may still be prohibitively expensive. There is a risk of project delays leading to a failure to supply at the agreed time; the demand project would then have to switch to another supply project or conventional suppliers (for legend, refer to Figure 2)

information and increase confidence on all sides that the transaction will be successful. Standard clauses would need to be developed for specifying components from the virtual warehouse, to align reuse with conventional procurement. The price and condition of recovered components would need to be agreed, and supply-side developers would specify in demolition contracts any recovery operations that differ from typical demolition.

\subsection{Component flows: reuse, repurposing and third- party upcycling}

Direct reuse or repurposing of components turns developers and demolition contractors into suppliers - for which capacity would need to be built - and makes the sourcing of materials a key driver in the early design stages, potentially influencing layout, structure and other parts of the design. This requires a change to the design process (Gorgolewski, 2008), for which, again, capacity would need to be built. Drivers include increasing recognition in the industry of circular economy principles and their application in construction (Adams et al., 2017) and external factors, such as potential increases in resource prices, carbon taxation and regulation of whole-life carbon (Rose and Stegemann, 2018). However, without relying on these pressures to change design practices, a process more in line with current procurement of both demolition and new construction can be envisaged, involving third parties between the supply project and the demand project (Figure 5).

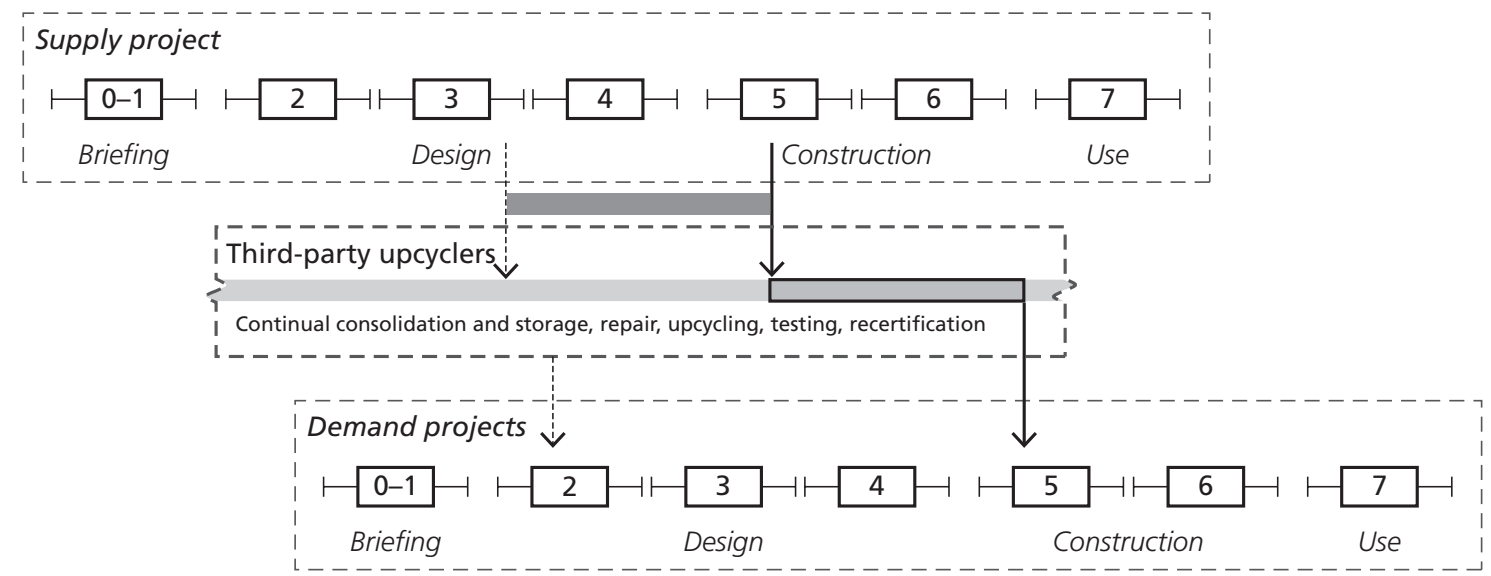

Figure 5. One or more third parties between supply and demand projects. Enterprises exploit new business opportunities based on E-BAMB information. Consolidation, upcycling, testing and recertification add value and allow products to reach a larger market segment. Products meet the same standards as virgin equivalents or new standards are created. Product information is available to demand projects at any time, more akin to that of a conventional supply chain. Third parties resolve supply project delay issues (for legend, refer to Figure 2) 
Third parties must add significant value to their feedstocks to cover costs. Efficiency gains through the E-BAMB information system may somewhat reduce salvage yards' supply costs, but increasing the scope for third-party reuse beyond high-end architectural salvage is likely to remain a challenge. Therefore, there is a need for new value-adding processes that maximise the difference between the cost of feedstock (or incoming waste disposal fees) and the market price for resulting products. Development of upcycling business opportunities is most likely in a situation where potential feedstocks are made visible and available. In a mature state, third parties would consolidate and process feedstocks continuously, absorbing or mitigating the effect of project delays and creating a viable alternative supply chain. The demand side's need for certainty over quality and quantity would be met by recertifying products and making them available within reasonable lead-in times. Local processing of discarded building components would create various new employment opportunities and a means for more local private and public spending.

\subsection{Feedback loop: codifying knowledge and assessing impact}

Recording reclamation and reuse facilitated through the virtual warehouse would codify repurposing ideas (as discussed in Section 4.5) and allow the measurement of waste prevention, avoided virgin material purchasing, and embodied carbon savings. These data could be used to establish feasible project benchmarks for reclamation and reuse, informing new incentives - for example, within the Building Research Establishment Environmental Assessment Method. Life-cycle assessments could verify the reductions in environmental impacts. Public procurement could require a quota of materials to be reclaimed from existing building stock, reused in new construction or both. Embodied carbon savings realised through reuse could contribute to reaching zero-carbon targets (e.g. GLA, 2014).

\section{Conclusions}

This paper presents a pragmatic assessment of the ways that components in existing buildings can be understood through research and practice. Currently the main methods available for understanding E-BAMB are not effective for enabling component reuse. No single approach addresses the full interface of supply and demand, nor are they organised together to form an effective information system. The paper deduces from the weaknesses and strengths of existing methods an improved system for gathering structured and timely information and using it to effect change within the industry. In the proposed system, RMMs are embellished with information from refocused pre-redevelopment audits, in-use stocks research and developments in scan-to-BIM technology. The process steps are integrated into normal procurement procedures. With further development, this would represent an early step in making reuse, repurposing and upcycling possible at scale.

Further research into the information system design will be needed to develop its operability, such as the ownership and maintenance of the E-BAMB database, its interface with BIM- enabled specification and means of navigating components' qualities within a large data set that can facilitate the identification of unexpected solutions to needs. The paper emphasises the importance of creative repurposing and upcycling alongside direct reuse and describes means of drawing on creative faculties within and around the construction industry. Further research could address specific material flows in detail and explore the viability of new business models. For example, the authors are currently examining the manufacture of structural cross-laminated timber using secondary timber as a principal feedstock, which would extend the high-value use of timber.

Existing policy endorses reuse, but mechanisms for implementing it are presently weak. The policy framework must move from recommendations that favour reuse into firm requirements and supporting measures that help to bring it about in the mainstream. To contribute to this shift, the paper describes how E-BAMB knowledge could be generated and used as a precursor to overcoming other constraints to reclamation and reuse. Given the uncertain extent of benefits that would accrue, it is ambitious to design a new information system and develop it as a feasible procurement route and optimistic to call for legislative change. However, without innovations along these lines, the prospects of achieving greater reuse are extremely slim. Advances are hampered by the difficulty of predicting levels of practical adoption of reuse in conditions that remain largely theoretical. Until the information and infrastructure to support reuse exists, it is hard to establish the extent to which it would benefit the industry, and until real benefits are proven, it is hard to justify investment in the types of innovation described in this paper. Further research could therefore investigate criteria for the adoption of reuse and the emergence of repurposing and upcycling ideas if the demand side of the market were exposed to more comprehensive E-BAMB information.

\section{Acknowledgements}

This paper is based on research undertaken as part of the Engineering and Physical Sciences Research Council project 'Developing systems to enable reuse of waste building components' (Grant Reference: EP/G037698/1). Co-funding and project supervision was provided by Poplar HARCA, Tower Hamlets Homes and University College London.

The authors would like to thank the staff at Poplar HARCA and Tower Hamlets Homes for their support in carrying out this research.

\section{REFERENCES}

Adams KT, Osmani M, Thorpe T and Thornback J (2017) Circular economy in construction: current awareness, challenges and enablers. Proceedings of the Institution of Civil Engineers - Waste and Resource Management 170(1): 15-24, https://doi.org/10.1680/jwarm. 16.00011.

Ali AK (2012) Re-defining the Architectural Design Process through Building a Decision Support Framework for Design with Reused Building Materials and Components. PhD thesis, Virginia Polytechnic Institute and State University, Blacksburg, VA, USA. 
Ali AK (2016) Transformation of emerging building materials reuse industry through mapping sustainable architectural design processes using BPMN. In Proceedings of the CIB World Building Congress: Creating Built Environments of New Opportunities (Kähkönen K and Keinänen M (eds)). Tampere University of Technology, Tampere, Finland, pp. 552-564.

Arayici Y (2008) Towards building information modelling for existing structures. Structural Survey 26(3): 210-222, https://doi.org/10.1108/ 02630800810887108

Augiseau V and Barles S (2016) Studying construction materials flows and stock: a review. Resources, Conservation and Recycling 123: 153-164, https://doi.org/10.1016/j.resconrec.2016.09.002.

Barazzetti L, Banfi F, Brumana R et al. (2015) Cloud-to-BIM-to-FEM: structural simulation with accurate historic BIM from laser scans. Simulation Modelling Practice and Theory 57: 71-87, https://doi.org/ 10.1016/j.simpat.2015.06.004.

Bell M (2004) Energy efficiency in existing buildings: the role of building regulations. In COBRA 2004: Proceedings of the RICS Foundation Construction and Building Research Conference (Ellis R and Bell M (eds)). Royal Institution of Chartered Surveyors, London, UK, pp. 7-8.

Bergsdal H, Brattebø H, Bohne RA and Müller DB (2007) Dynamic material flow analysis for Norway's dwelling stock. Building Research \& Information 35(5): 557-570, https://doi.org/10.1080/ 09613210701287588.

Bin S, Zhiquan Y, Jonathan LSC et al. (2015) A big data analytics approach to develop industrial symbioses in large cities. Procedia CIRP 29: 450-455, https://doi.org/10.1016/j.procir.2015.01.066.

Bioregional (2011) Reuse and Recycling on the London 2012 Olympic Park: Lessons for Demolition, Construction and Regeneration. Bioregional, Wallington, UK.

Bossink B and Brouwers H (1996) Construction waste: quantification and source evaluation. Journal of Construction Engineering and Management 122(11): 55-60, https://doi.org/10.1061/(ASCE)07339364(1996)122:1(55).

Brewer G and Mooney J (2008) A best practice policy for recycling and reuse in building. Proceedings of the Institution of Civil Engineers Engineering Sustainability 161(3): 173-180, https://doi.org/10.1680/ ensu.2008.161.3.173.

Carris J (2011) Learning Legacy: Demolition Waste Management on the Olympic Park. Olympic Delivery Authority, London, UK.

Chen Z, Li H, Kong SCW, Hong J and Xu Q (2006) E-commerce system simulation for construction and demolition waste exchange. Automation in Construction 15(6): 706-718, https://doi.org/10.1016/j autcon.2005.09.003.

Coelho A and de Brito J (2011) Generation of construction and demolition waste in Portugal. Waste Management \& Research 29(7): 739-750, https://doi.org/10.1177/0734242X11402253.

CPIC (Construction Project Information Committee) (1998) Common Arrangement of Work Sections for Building Works. CPIC, Alton, UK.

Crawford K, Johnson C, Davies F, Joo S and Bell S (2014) Demolition or Refurbishment of Social Housing? A Review of the Evidence. University College London, London, UK.

CRWP (Construction Resources and Waste Platform) and Salvo (2007) BigREc Survey: a Survey of the UK Reclamation and Salvage Trade. CRWP, Watford, UK.

Debacker W and Manshoven S (2016) D1 Synthesis of the State-of-theart: Key Barriers and Opportunities for Materials Passports and Reversible Building Design in the Current System. BAMB, Ronneby, Sweden.

Defra (Department for Environment, Food and Rural Affairs) (2013) Waste Management Plan for England. Defra, London, UK.

Densley Tingley D, Cooper S and Cullen J (2017) Understanding and overcoming the barriers to structural steel reuse, a UK perspective. Journal of Cleaner Production 148: 642-652, https://doi.org/10.1016/ j.jclepro.2017.02.006.
Dunant CF, Drewniok MP, Sansom M et al. (2017) Real and perceived barriers to steel reuse across the UK construction value chain. Resources, Conservation and Recycling 126: 118-131, https://doi.org/ 10.1016/j.resconrec.2017.07.036

Durmišević E (2015) Buildings as material banks. In The 3rd International Conference: 'the Importance of Place' (Popovac MR, IdrizbegovićZgonić A, Klarić S, Rustempašić N and Čausević A (eds)). BH Cicop, Sarajevo, Bosnia and Herzegovina, pp. 139-152.

EC (European Community) (2000) Commission Decision of 3 May 2000 replacing Decision 94/3/EC establishing a list of wastes pursuant to Article 1(a) of Council Directive 75/442/EEC on waste pursuant to Article 1(4) of Council Directive 91/689/EEC on hazardous waste (notified under document number C(2000) 1147). Official Journal of the European Communities L226.

EC (2008) Directive 2008/98/EC of the European Parliament and of the Council of 19 November 2008 on waste and repealing certain Directives. Official Journal of the European Communities L312/3

Ergun D and Gorgolewski M (2015) Inventorying Toronto's single detached housing stocks to examine the availability of clay brick for urban mining. Waste Management 45: 180-185, https://doi.org/10. 1016/j.wasman.2015.03.036.

European Commission (2015) Closing the Loop - an EU Action Plan for the Circular Economy. European Commission, Brussels, Belgium, https://doi.org/10.1017/CBO9781107415324.004.

Giesekam J, Barrett JR and Taylor P (2015) Construction sector views on low carbon building materials. Building Research \& Information 3218: 1-23, https://doi.org/10.1080/09613218.2016.1086872.

Giesekam J, Barrett J and Taylor P (2016) Scenario analysis of embodied greenhouse gas emissions in UK construction. Proceedings of the Institution of Civil Engineers - Engineering Sustainability 171(4) 178-190, https://doi.org/10.1680/jensu.16.00020.

GLA (Greater London Authority) (2014) Sustainable Design and Construction: Supplementary Planning Guidance. GLA, London, UK.

GLA (2016) The London Plan: Consolidated with Alterations since 2011. GLA, London, UK

GLA (2018) London Environment Strategy. GLA, London, UK.

Gorgolewski M (2000) The recycled building project. In Sustainable Building (Boonstra C, Rovers R and Pauwels S (eds)). Aeneas, Maastricht, the Netherlands, pp. 125-127.

Gorgolewski M (2008) Designing with reused building components: some challenges. Building Research \& Information 36: 175-188, https://doi. org/10.1080/09613210701559499.

Gorgolewski M and Ergun D (2013) Closed-loop materials systems. Sustainable Building Conference 2013, Coventry, UK, pp. 235-243.

Gorgolewski M, Straka V, Edmonds J and Sergio C (2006) Facilitating Greater Reuse and Recycling of Structural Steel in the Construction and Demolition Process. Canadian Institute for Steel Construction (CISC), Toronto, ON, Canada. See http://www.nrcan.gc.ca/sites/www. nrcan.gc.ca/files/mineralsmetals/pdf/mms-smm/busi-indu/rad-rad/pdf/ re-ste-fin-eng.pdf (accessed 31/08/2018).

Guggemos AA and Horvath A (2003) Strategies of extended producer responsibility for buildings. Journal of Infrastructure Systems 9(2): 65-74, https://doi.org/10.1061/(ASCE)1076-0342(2003)9:2(65).

Heiskanen A (2017) The technology of trust: how the Internet of Things and blockchain could usher in a new era of construction productivity. Construction Research and Innovation 8(2): 66-70, https://doi.org/10. 1080/20450249.2017.1337349

Hinnells M, Boardman B, Layberry R, Darby S and Killip G (2007) The UK Housing Stock 2005 to 2050: Assumptions Used in Scenarios and Sensitivity Analysis in UKDCM2. Environmental Change Institute, University of Oxford, Oxford, UK.

HMG (Her Majesty's Government) (2008) The Site Waste Management Plans Regulations 2008. The Stationery Office, London, UK, Statutory Instrument 2008 No. 314. 
HMG (2017) The Clean Growth Strategy: Leading the Way to a Low Carbon Future. The Stationery Office, London, UK.

Hobbs G, Adams K and Blackwell M (2011) Understanding and predicting construction waste. Proceedings of the Institution of Civil Engineers Waste and Resource Management 164(4): 239-245, https://doi.org/10. 1680/warm.2011.164.4.239.

Horvath A (2004) Construction materials and the environment. Annual Review of Environment and Resources 29: 181-204, https://doi.org/10 1146/annurev.energy.29.062403.102215.

Hurley JW (2003) Valuing the pre-demolition audit process. In Proceedings of the 11th Rinker International Conference on Deconstruction and Materials Reuse (Chini AR (ed.)). International Council for Research and Innovation in Building Construction, Gainesville, FL, USA, pp. 151-164.

Huuhka S, Kaasalainen T, Hakanen JH and Lahdensivu J (2015) Reusing concrete panels from buildings for building: potential in Finnish 1970s mass housing. Resources, Conservation and Recycling 101: 105-121, https://doi.org/10.1016/j.resconrec.2015.05.017.

lacovidou E and Purnell P (2016) Mining the physical infrastructure: opportunities, barriers and interventions in promoting structural components reuse. Science of the Total Environment 557-558: 791-807, https://doi.org/10.1016/j.scitotenv.2016.03.098.

ICE (Institution of Civil Engineers) (2008) Demolition Protocol 2008. ICE, London, UK.

Jongert J, Nelson N and Goosens F (2011) Recyclicity: a toolbox for resource-based design. Architectural Design 81(6): 55-61, https://doi. org/10.1002/ad.1320.

Kay T (1994) Reiner Pilz. Salvo Monthly 23: 11-14. See http://www. nrutech. com/wp-content/uploads/2014/09/ 1994 Salvo Reiner Pilz Upcycling.pdf (accessed 16/01/2018).

Kleemann F, Lederer J, Aschenbrenner P, Rechberger $\mathrm{H}$ and Fellner J (2016) A method for determining buildings' material composition prior to demolition. Building Research \& Information 44(1): 51-62, https://doi.org/10.1080/09613218.2014.979029.

Kohler N and Hassler U (2002) The building stock as a research object. Building Research \& Information 30(4): 226-236, https://doi.org/10. 1080/09613210110102238.

Kral U, Lin CY, Kellner K, Ma HW and Brunner PH (2014) The copper balance of cities: exploratory insights into a European and an Asian City. Journal of Industrial Ecology 18(3): 432-444, https://doi.org/10. $1111 /$ jiec. 12088 .

Luscuere LM (2017) Materials Passports: Optimising value recovery from materials. Proceedings of the Institution of Civil Engineers - Waste and Resource Management 170(1): 25-28, https://doi.org/10.1680/ jwarm.16.00016.

LWARB (London Waste and Recycling Board) (2017) London's Circular Economy Route Map - Circular London. LWARB, London, UK.

Macozoma DS (2001) Building Deconstruction: International Report. International Council for Research and Innovation in Building and Construction (CIB), Pretoria, South Africa.

McGinley T (2015) JunkUp: supporting e-procurement of used materials in the construction industry using eBay and BIM. Unmaking Waste 2015, Adelaide, Australia, pp. 241-251.

Müller DB (2006) Stock dynamics for forecasting material flows - case study for housing in the Netherlands. Ecological Economics 59(1): 142-156, https://doi.org/10.1016/j.eco lecon.2005.09.025.

Murphy M, McGovern E and Pavia S (2009) Historic building information modelling (HBIM). Structural Survey 27(4): 311-327, https://doi.org/ 10.1108/02630800910985108.

Mustow SE (2006) Procurement of ethical construction products. Proceedings of the Institution of Civil Engineers - Engineering Sustainability 159(1): 11-21, https://doi.org/10.1680/ensu.2006.159.1.11

NBS (National Building Specification) (2015) Uniclass 2015 - a Universal Classification System for the Construction Industry. NBS, Newcastle upon Tyne, UK. See https://www.thenbs.com/news/uniclass-2015-a- universal-classification-system-for-the-construction-industry (accessed 25/10/2017).

Ness D, Swift J, Ranasinghe DC et al. (2015) Smart steel: new paradigms for the reuse of steel enabled by digital tracking and modelling. Journal of Cleaner Production 98: 292-303, https://doi.org/10.1016/j. jclepro.2014.08.055.

NFDC (National Federation of Demolition Contractors) and IDE (Institute of Demolition Engineers) (2016) Demolition and Refurbishment: Resource Protocol. NFDC, Hemel Hempstead, UK.

Pereira NC, Datta S and Mancini FM (2016) Material (re)contextualization: goal establishment in means-oriented architectural design. In Eco Architecture VI: Harmonisation between Architecture and NatureVolume 161 of WIT Transactions on the Built Environment (Echarri V and Brebbia CA (eds)). WIT Press, Southampton, UK, pp. 83-92.

Poelman WA (2009) Supply driven architecture (SDA). In Lifecycle Design of Buildings, Systems and Materials: CIB W115 Construction Material Stewardship (Durmišević E (ed.)). International Council for Building Research Studies and Documentation (CIB), Working Commission W115 and the University of Twente, the Netherlands, Rotterdam, the Netherlands, pp. 110-117.

Power A (2010) Housing and sustainability: demolition or refurbishment? Proceedings of the Institution of Civil Engineers - Urban Design and Planning 163(4): 205-216, https://doi.org/10.1680/udap.2010.163.4. 205.

Pun SK and Liu C (2006) A framework for material management in the building demolition industry. Architectural Science Review 49(4): 391-398, https://doi.org/10.3763/asre.2006.4951.

Pun SK, Liu C, Treloar G, Langston C and Itoh Y (2003) Development of a web-based information system for cascading utilisation of construction materials. Aubea 2003: Working Together: Proceedings of the 28th Annual Conference of the Australasian Universities Building Educators Association, Deakin University, Geelong, Australia, pp. 293-300

Resource Efficient Scotland (2017) Maximising Re-use. Resource Efficient Scotland, Stirling, UK.

RIBA (Royal Institute of British Architects) (2013) Plan of Work 2013 View the Plan (Stage 0). RIBA, London, UK. See https://www. ribaplanofwork.com/PlanOfWork.aspx (accessed 11/10/2017).

Rose CM and Stegemann JA (2018) From waste management to component management in the construction industry. Sustainability 10(229): 1-21, https://doi.org/10.3390/su10010229.

RSA (Royal Society for the Encouragement of Arts, Manufactures and Commerce) and The Great Recovery (2015) North Sea Oil and Gas Rig Decommissioning and Re-use Opportunity Report. RSA, London, UK.

Schebek L, Schnitzer B, Blesinger D et al. (2017) Material stocks of the non-residential building sector: the case of the Rhine-Main area. Resources, Conservation and Recycling 123: 24-36, https://doi.org/10. 1016/j.resconrec.2016.06.001.

Sieffert Y, Huygen JM and Daudon D (2014) Sustainable construction with repurposed materials in the context of a civil engineeringarchitecture collaboration. Journal of Cleaner Production 67: 125-138, https://doi.org/10.1016/j.jclepro.2013.12.018.

Superuse Studios (2017a) Harvest Map - Marketplace for Professional Upcyclers. Superuse Studios, Rotterdam, the Netherlands. See https:// www.oogstkaart.nl/oogstkaart/ (accessed 02/11/2017).

Superuse Studios (2017b) Architecture - Homepage of One of the Most Advanced Specialists on Flow Based Design and Research. Superuse Studios, Rotterdam, the Netherlands. See http://superuse-studios.com/ index.php/category/re-build/ (accessed 25/10/2017).

Susanty A, Sari DP, Budiawan W, Sriyanto and Kurniawan H (2016) Improving green supply chain management in furniture industry through Internet based geographical information system for connecting the producer of wood waste with buyer. Procedia Computer Science 83: 734-741, https://doi.org/10.1016/j.procs.2016.04.161. 
Engineering Sustainability

Volume 172 Issue ES3
Characterising existing buildings as

material banks (E-BAMB) to enable

component reuse

Rose and Stegemann
Swift J, Ness D, Chileshe N et al. (2015) Enabling the reuse of building components: a dialogue between the virtual and physical worlds. Unmaking Waste 2015: Zero Waste, SA Research Centre for Sustainable Design and Behaviour, School of Art, Architecture and Design, University of South Australia, Adelaide, Australia, pp. 252-260.

Tanikawa $\mathrm{H}$ and Hashimoto S (2009) Urban stock over time: spatial material stock analysis using 4d-GIS. Building Research \& Information 37(5-6): 483-502, https://doi.org/10.1080/09613210903169394.

Tanikawa H, Hashimoto S and Moriguchi Y (2002) Estimation of material stock in urban civil infrastructures and buildings for the prediction of waste generation. Proceedings of the Fifth International Conference on EcoBalance, 6-8 November, Tsukuba, Japan, pp. 1-4.

The National Archives (2012) Records Management Retention Scheduling: 1. Buildings Records. The National Archives, Kew, UK

Thomsen A and van der Flier K (2011) Understanding obsolescence: a conceptual model for buildings. Building Research \& Information 39(4): 352-362, https://doi.org/10.1080/09613218.2011.576328.

van der Flier K and Thomsen A (2006) Life cycle of dwellings and demolition by Dutch housing associations. In Sustainable Neighbourhood Transformation (Gruis V, Visscher H and Kleinhans R (eds)). IOS Press, Delft, the Netherlands, pp. 23-41.

Van Ewijk S and Stegemann JA (2016) Limitations of the waste hierarchy for achieving absolute reductions in material throughput. Journal of Cleaner Production 132: 122-128, https://doi.org/10.1016/j.jclepro. 2014.11.051 van Hinte E, Peeren C and Jongert J (2007) Superuse: Constructing New Architecture by Shortcutting Material Flows. 010 Publishers, Rotterdam, the Netherlands.

Vásquez F, Løvik AN, Sandberg NH and Müller DB (2016) Dynamic typecohort-time approach for the analysis of energy reductions strategies in the building stock. Energy and Buildings 111: 37-55, https://doi.org/ 10.1016/j.enbuild.2015.11.018

Volk R, Stengel J and Schultmann F (2014) Building Information Modeling (BIM) for existing buildings - literature review and future needs. Automation in Construction 38: 109-127, https://doi.org/10. 1016/j.autcon.2013.10.023.

Volk R, Sevilmis N and Schultmann F (2015) Deconstruction project planning based on automatic acquisition and reconstruction of building information for existing buildings. In Smart and Sustainable Build Environments 2015 (SSBE) (Gibberd J and Conradie DCU (eds)). CIB, CSIR, University of Pretoria, Pretoria, South Africa, pp. $47-56$.

Wiedenhofer D, Steinberger JK, Eisenmenger N and Haas W (2015) Maintenance and expansion: modeling material stocks and flows for residential buildings and transportation networks in the EU25. Journal of Industrial Ecology 19(4): 538-551, https://doi.org/10.1111/ jiec. 12216.

Wu Z, Yu ATW, Shen L and Liu G (2014) Quantifying construction and demolition waste: an analytical review. Waste Management 34(9): 1683-1692, https://doi.org/10.1016/j.wasman.2014.05.010.

\section{How can you contribute?}

To discuss this paper, please email up to 500 words to the editor at journals@ice.org.uk. Your contribution will be forwarded to the author(s) for a reply and, if considered appropriate by the editorial board, it will be published as discussion in a future issue of the journal.

Proceedings journals rely entirely on contributions from the civil engineering profession (and allied disciplines). Information about how to submit your paper online is available at www.icevirtuallibrary.com/page/authors, where you will also find detailed author guidelines. 